\title{
Analisis Hasil Simulasi Sifat Mekanik Single Walled Carbon Nanotube dengan Metode Elemen Hingga
}

\author{
Ayu Furoidah, Mas Irfan P. Hidayat, dan Diah Susanti \\ Departemen Teknik Material, Fakultas Teknologi Industri, Institut Teknologi Sepuluh Nopember (ITS) \\ e-mail : irfan@mat-eng.its.ac.id
}

\begin{abstract}
Abstrak-Carbon nanotube merupakan material allotropi carbon yang memiliki sifat mekanik, thermal dan elektrik cukup baik. Saat ini para peneliti masih banyak menganalisa kebutuhan sifat mekanik yang tepat untuk dapat diterapkan lebih diberbagai bidang. Ukurannya yang nano membuat sulitnya pengujian untuk menganalisa sifat dan perilaku CNT. Sehingga diperlukan adanya simulasi komputasi untuk menyederhanakan penelitian. Hasil simulasi dibuat untuk menganalisa sifat mekanik berupa modulus elastisitas SWCNT dengan membandingkan variasi struktur tipe zigzag dan armchair menggunakan software ANSYS 17.1 Mechanical APDL. Hasil simulasi juga digunakan untuk menganalisa pengaruh diameter, ketebalan, dan aspek rasio terhadap nilai Young's modulus SWCNT. Diperoleh bahwa struktur yang sesuai untuk aplikasi yang membutuhkan tingkat kelenturan yang tinggi akibat pembebanan bending dan buckling adalah struktur armchair. Dimana semakin besar diameter single walled carbon nanotube maka nilai Young's modulusnya. Semakin meningkat. Dan semakin tinggi aspek rasio dan ketebalan struktur SWCNT maka semakin rendah nilai Young's modulusnya.
\end{abstract}

Kata Kunci-Carbon nanotube, Bending, Buckling, Young's Modulus

\section{PENDAHULUAN}

$\mathrm{C}$ ARBON nanotube merupakan struktur yang berukuran nano dan menjadi hal yang menarik dari allotropi karbon karena dikenal memiliki sifat mekanik dan elektronik yang sangat baik. [1] Penemuan dari berbagai bentuk carbon nanotube (CNT) telah memotivasi researcher untuk mengaplikasikannya dalam berbagai bidang. Seperti bidang medis, nanoteknologi, manufaktur, konstruksi, elektronik, dan lain sebagainya. Penemuan Lee dkk [2] misalnya dalam bidang komposit yang menggunakan tambahan karbon nanotube sebagai serat karbon dapat meningkatkan kekuatan mekanik dan elektrik dari komposit yang terbentuk.[2] Carbon nanotube baik single walled maupun multi walled juga dapat digunakan sebagai implant buatan tanpa respon penolakan dari host, rekayasa jaringan organ, identifikasi sel kanker, dan sebagainya

Teknologi untuk penelitian dan pengembangan material seperti bahan allotropi dari carbon, salah satunya carbon nanotube, masih membutuhkan dana yang cukup tinggi. Sehingga dapat diambil terobosan lain yaitu dengan melakukan simulasi finite element method. Metode elemen hingga (finite element method) merupakan suatu metode diskrit dimana massa dapat direpresentasikan dalam nodal struktur, sehingga dapat memodelkan distribusi massa yang kontinyu pada struktur. Member struktur dibagi-bagi menjadi elemen-elemen yang lebih kecil dengan jumlah yang secara teoretis tak berhingga. Salah satu software dengan prinsip tersebut adalah ANSYS. Penggunaan simulasi dengan ANSYS dilakukan karena lebih efisien waktu dan harga.

Beberapa penelitian telah dilakukan untuk menganalisa sifat mekanik carbon nanotube menggunakan simulasi dengan berbagai metode, antara lain molecular dinamik, finite element, dan prediksi analitik. Menggunakan perhitungan mekanika continuum dan interaksi interatomik untuk menentukan tingkat elastisitas atau kekakuan carbon nanotube. Kemudian juga menganalisa berbagai pengaruh variabel muali dari diameter, aspek rasio, kiralitas, dan ketebalan yang dinyatakan belum ada nilai spesifik yang pasti akan nilai ketebalan dari carbon nanotube.

Penelitian berikut dilakukan untuk menganalisa struktur single walled carbon nanotube tipe zigzag dan armchair dengan orientasi tertentu menggunakan ANSYS Mechanical ADPL 17.1 agar dapat menggambarkan sifat mekanik berupa nilai Young's modulus dan nilai maksimum pembebanan bending dan buckling yang diberikan.

\section{METODE PENELITIAN}

\section{A. Struktur Dasar SWCNT}

Struktur SWNT menggambarkan one-atom-thick layer dari graphene yang digulung menjadi sebuah silinder. Karakteristik dasar nanotube dapat digambarkan oleh dua vektor, Ch dan T (Gambar 1). Ch dianggap sebagai vektor dalam lembar graphene yang menggambarkan keliling permukaan tube yang menghubungkan dua atom karbon yang sejenis. Persamaan panjang chiral berupa $\mathrm{Ch}=$ nâ $1+$ mâ2. Sedangkan T dinotasikan sebagai axis, dengan â1 dan â2 sebagai 2 basis vektor grafit dan $\mathrm{n}$ serta m merupakan bilangan bulat $\mathrm{n}$ dan $\mathrm{m}$ juga disebut dengan index untuk menentukan sudut chiral [3]

$\pi=\tan -1[(\sqrt{3} \mathrm{n}) /((2 \mathrm{~m}+\mathrm{n}))]$

Sudut chiral digunakan untuk memisahkan carbon nanotube menjadi tiga kelas berbeda berdasarkan sifat elektroniknya: 
armchair $\left(\mathrm{n}=\mathrm{m}, \pi=30^{\circ}\right)$, contoh $(8,8)$

zig-zag $\quad\left(\mathrm{m}=0, \mathrm{n}>0, \pi=0^{\circ}\right)$, contoh $(10,0)$

chiral $\quad\left(0<|\mathrm{m}|<\mathrm{n}, 0<\pi<30^{\circ}\right)$, contoh $(7,9)$

Diameter nanotube dapat ditunjukkan dengan persamaan berikut,

$$
\mathrm{dt}=\sqrt{\frac{3 \mathrm{x} a_{\mathrm{C}-\mathrm{c}}(\operatorname{mg} 2+\operatorname{mn}+\mathrm{n} 2) 0,5}{\pi}}=\frac{\mathrm{Ch}}{\pi}
$$

Ch adalah panjang $\mathrm{Ch}$, dan $\mathrm{a}_{\mathrm{c}-\mathrm{c}}$ adalah panjang ikatan $\mathrm{C}-\mathrm{C}$ $(1.42 \AA)[4]$

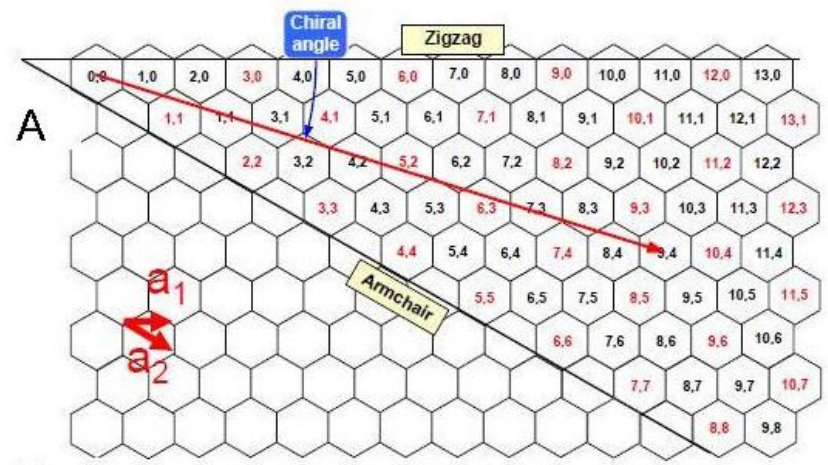

Gambar 1. Lembaran graphene ditandai dengan bilangan bulat/integer $(\mathrm{n}, \mathrm{m})$.Diameter sudut chiral dan jenisnya diketahui dengan bilangan

\section{B. Pembuatan Geometri dan Pembebanan}

Dalam studi simulasi numerik, Geometri SWCNT dibangun menggunakan penulisan makro dalam software Parametric Design Language (APDL). Element BEAM 188 dipilih untuk analisis non linier beam element. SWCNT dimodelkan menggunakan keypoint dan line. Dengan menggunakan 6 titik koordinat sesuai dengan ukuran primitive vector.

$$
\begin{aligned}
& \mathrm{a}_{1}=\left(\frac{1}{2}, \frac{\sqrt{2}}{2}\right) \mathrm{a} \sqrt{3} \\
& \mathrm{a}_{2}=\left(\frac{1}{2}, \frac{\sqrt{3}}{2}\right) \mathrm{a} \sqrt{3}
\end{aligned}
$$

Proses penyusunan geometri armchair berdasarkan variasi diameter ditentukan dari jumlah hexagonal dalam satu lingkaran. Gambar 2 menggambarkan geometri armchair $(5,5)$ yang diwakilkan dengan 4 buah lingkaran dasar berjarak $1 \AA$ dan berdiameter 6.9Å. Menggunakan command DIVIDE pada Modelling-Operate-Boolean membagi masing-masing lingkaran menjadi 60 bagian. Dengan dibagi skala 4:8 untuk garis tertutup dan terbuka dihubungkan garis antar lingkaran dan dihapus garis semu lingkaran yang tidak terpakai guna menyempurnakan bentuk hexagonal. Selanjutnya dilakukan penambahan sejumlah pasang dengan command COPY

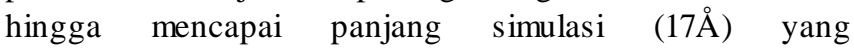
menggambarkan komponen structural space frame carbon nanotube.

Geometri Zigzag juga dibuat dengan proses yang sama dengan armchair, namun skala perbandingannya berbeda meski berdiameter sama dengan armchair $(5,5)$ untuk zigzag $(9,0)$. Lingkaran dasar digambarkan dengan diameter sesuai tipe $(9,0)$ dicopy sebanyak dua kali lipat dari penggandaan lingkaran dasar untuk armchair. Kemudian dengan command sama yaitu Modelling-Operate-Boolean membagi masingmasing lingkaran menjadi 9 bagian. Lalu dihubungkan garis antar potongan membentuk hexagonal-hexagonal berjajar. Dan disempurnakan dengan penghapusan garis dasar lingkaran. Setelah terbentuk sempurna dua baris hexagonal melingkar, lalu digandakan kea rah $\mathrm{z}=\mathrm{h}$.
Kemudian dilakukan analisis sifat mekanik pada dua jenis SWCNT yaitu tipe zigzag dan armchair dengan pembebanan bending (pemberian gaya secara axial pada titik tekuk) dan buckling (pemberian gaya kompresi sampai pada titik tekuk material), sehingga dapat terlihat kelenturan dan nilai Young's modulus lembar CNT tersebut.

Kondisi batas diterapkan. Semua derajat kebebasan setiap keypoint ditangkap di salah satu ujung struktur sementara gaya kompresi (buckling) mengarah pada komponen $\mathrm{Z}$ dan bending yang mengarah pada komponen $X$ diterapkan pada setiap ujung keypoint. POST PROCESSING, solution nodal diperoleh dan perpindahan pada arah komponen $\mathrm{X}$ dan $\mathrm{Z}$ diperoleh. (Gambar 3) Terakhir Modulus Young dihitung.

Sifat mekanik dari struktur space-frame CNT dianalisa menggunakan metode mekanika classic struktural dengan memodelkan ikatan, digunakan jenis elemen elastis 3D dan digambarkan oleh titik/ nodes yang dinyatakan dalam

$(\mathrm{x}, \mathrm{y}, \mathrm{z})=\left(\operatorname{Rcos}\left(\frac{x^{r}}{R}\right), \mathrm{r} \sin \left(\frac{x^{r}}{R}\right), y^{r}\right)$

Nodes menghubungkan elemen beam, menunjukkan gaya interatomic. (Gambar 4)
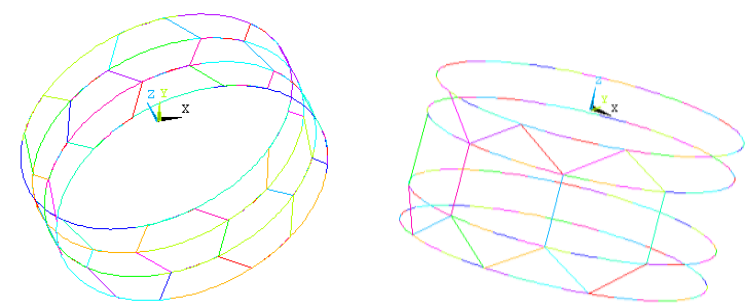

Gambar 2. Lingkaran dasar dan membagi menjadi beberapa hexagonal tipe armchair dan zigzag.

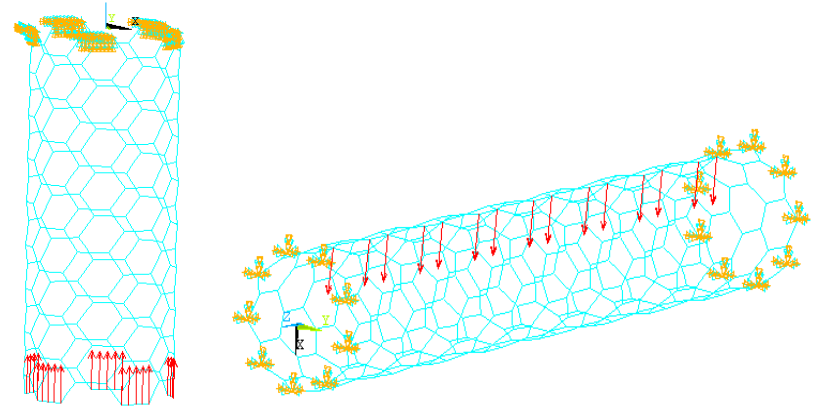

Gambar 3. Pembebanan Bending dan Buckling pada masing-masing tipe armchair dan zigzag

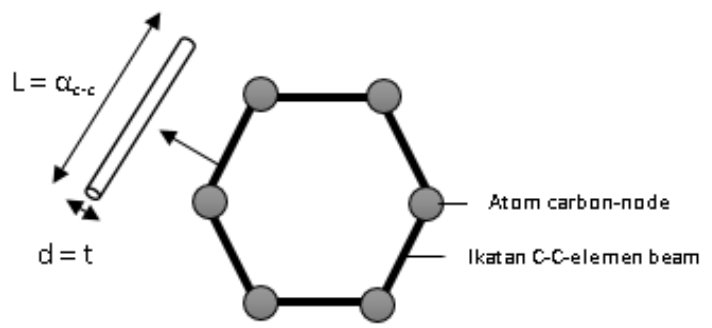

Gambar 4. Struktur 3D Space-frame CNT [5]

\section{HASIL DAN DISKUSI}

\section{A. Bending dan Buckling}

Terdapat 2 jenis pembebanan yang dilakukan pada simulasi ini, yaitu pembebanan buckling dan bending (Gambar 3). Buckling adalah kondisi dimana carbon 
nanotube mengalami ketidakstabilan saat dikenai pembebanan yang mengarah pada kegagalan akibat ketidamampuannya mempertahankan struktur awal. Sehingga akan terjadi deformasi yang biasa dikenal sebagai kondisi tekuk. Sedangkan bending adalah proses penekukan pada carbon nanotube setelah diberikan pembebanan.

Pada penelitian ini pembebanan buckling tipe armchair dilakukan ke arah sumbu $\mathrm{z}$ pada semua node $\mathrm{z}=\mathrm{h}$ dengan nilai Fz sebesar $1.25 \mathrm{E}+11 \mathrm{~Pa}$, sedangkan sisi lainnya di constraint tepatnya pada $\mathrm{z}=0$. Pembebanan bending dilakukan di setiap node dalam satu garis lurus yang searah sumbu $x$ dengan besar nilai Fx yang sama untuk tipe armchair sebesar $1.25 \mathrm{E}+11 \mathrm{~Pa}$.

Sedangkan pada SWCNT tipe zigzag pembebanan buckling dilakukan di setiap node yang melingkar pada $\mathrm{z}=\mathrm{h}$ dan diberi pembebanan Fx sebesar 9.40E+10 Pa. Dan untuk pembebanan bending dilakukan dengan cara yang sama seperti bending pada tipe armchair dilakukan di setiap node dalam satu garis lurus yang searah sumbu $\mathrm{x}$ dengan besar nilai Fx sebesar 9.40E+10 Pa.

Data yang diperoleh menunjukkan nilai tekuk maksimum pada setiap tipe yang dilakukan pembebanan. Pembebanan buckling didapatkan nilai $\varepsilon$ pada tipe armchair sebesar $1.19 \mathrm{E}+09 \mathrm{~nm}$ dan pada tipe zigzag sebesar 2.68E+08 nm. Hal ini bernilai sama pada pembebanan bending. Nilai tersebut didapatkan dari simulasi yang hanya pada ketebalan spesifik $0.34 \mathrm{~nm}$.

Jika melihat hasil simulasi dari tiap perbedaan diameter dari lima jenis tipe kiral armchair dan zigzag, dapat digambarkan oleh kurva pada gambar 5. Dari grafik terlihat nilai Young's modulus dimana berarti perbandingan stress strain akan meningkat seiring dengan peningkatan diameter dari kedua tipe SWCNT tersebut. Dan terlihat bahwa tipe armchair memiliki nilai Young's modulus lebih besar dibandingkan tipe zigzag.

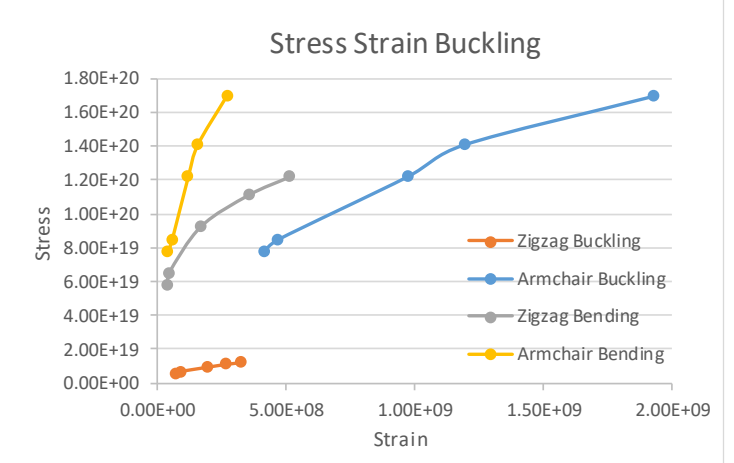

Gambar 5. Hasil simulasi Pembebanan Bending dan Buckling pada SWCNT

\section{B. Interaksi Interatomik}

Dalam perhitungan mekanika molecular, penting untuk mendeskripsikan gaya pada struktur material nano antaratom. Hal tersebut dikarakteristikan ke dalam force field. Force field ini dinyatakan dalam bentuk energi potensial steric. Energi potensial yang menghilangkan interaksi elektrostatik, didefinisikan sebagai total energi interaksi interatomik.

$$
\boldsymbol{U}=\boldsymbol{\Sigma} \boldsymbol{U}_{\boldsymbol{r}}+\boldsymbol{\Sigma} \boldsymbol{U} \boldsymbol{\theta}+\boldsymbol{\Sigma} \boldsymbol{U} \dot{\varnothing}+\boldsymbol{\Sigma} \boldsymbol{U}_{\omega}+\boldsymbol{\Sigma} \boldsymbol{u} \boldsymbol{v} \boldsymbol{w}
$$

merupakan energi yang dikarenakan dihedral angle torsion, $\mathrm{U}_{\omega}$ adalah energi yang diakibatkan oleh plane torsion dan $\mathrm{U}_{\mathrm{vdw}}$ adalah energi yang dikarenakan interaksi van der Waals yang tidak berikatan. (Gambar 7)

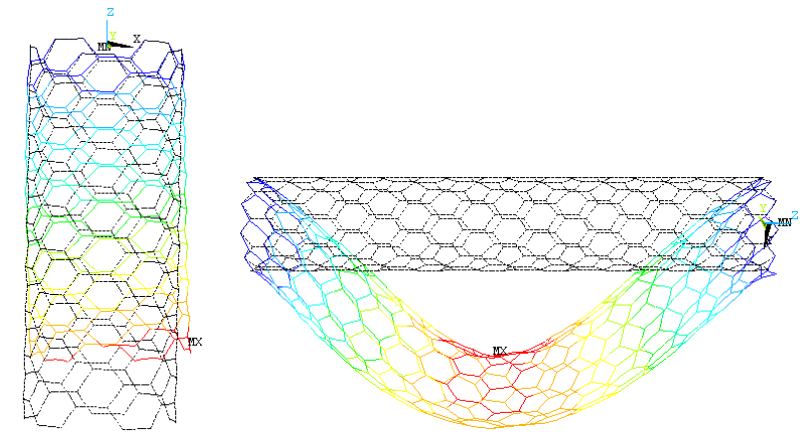

Gambar 6. Hasil simulasi Pembebanan Bending dan Buckling pada SWCNT

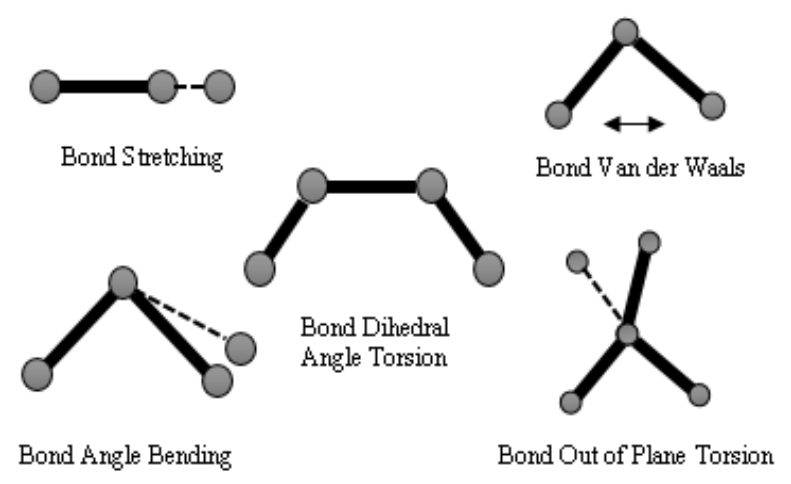

Gambar 7. Interaksi interatomic dalam mekanika molekular

Dengan asumsi deformasi yang kecil, perkiraaan harmonik cukup digunakan untuk mendefinisikan energi potensial dan selanjutnya disebut dengan force field. Dengan mengambil bentuk harmonik sederhana dan mengkombinasikan dengan sudut dihedral, torsi dengan out of plane torsion menjadi fungsi single ekuivalen dan dilanjutkan dengan fungsi deskripsi total.

$$
\begin{aligned}
\mathrm{U}_{\mathrm{r}} & =\frac{1}{2} \mathrm{k}_{\mathrm{r}}(\Delta \mathrm{r})^{2} \\
\mathrm{U}_{\mathrm{r}} & =\frac{1}{2} \mathrm{k}_{\Theta}(\Delta \Theta)^{2} \\
\mathrm{U}_{\tau} & =\mathrm{U} \varnothing \dot{ }+\mathrm{U}_{\omega}=\frac{1}{2} \mathrm{k}_{\tau}(\Delta \varnothing)^{2}
\end{aligned}
$$

$\mathrm{k}_{\mathrm{r}}, \mathrm{k}_{\Theta}, \mathrm{k}_{\tau}$ adalah bond stretching, ikatan sudut bending dan resistansi gaya torsi tetap. Sedangkan $\Delta \mathrm{r}, \Delta \Theta, \Delta \dot{\text { adalah }}$ panjang ikatan, sudut ikatan dan variasi ikatan sudut twisting.

\section{C.Young's Modulus Elemen Beam}

Luas permukaan melintang dari ikatan diasumsikan sebagai circular. Dan modulus elastis didefinisikan sebagai energi karena interaksi interatomic dan energi akibat deformasi struktur elemen space frame.

Pada penelitian ini model finite element digunakan untuk mengetahui efek ketebalan, diameter dan kiralitas pada Young's modulus SWCNT. Young's modulus material merupakan perbandingan stress dengan normal strain yang diketahui dari uji uni-axial kompresi (buckling) dan bending . Didefinisikan sebagai berikut:

Ur merupakan energi yang dikarenakan bond stretching, sedangkan Uo merupakan energi bond angle bending, Uǿ 


$$
\mathrm{Y}=\frac{\sigma}{\mathrm{s}}=\frac{\frac{\mathrm{F}}{\mathrm{A}}}{\frac{\mathrm{Ah}}{\mathrm{h}}}
$$

F merupakan besar total gaya yang diberikan, A0 luas permukaan, h panjang CNT, dan $\Delta \mathrm{h}$ merupakan elongation yang didapat dari simulasi ANSYS 17.1 Mechanical APDL plot hasil DOF displacement dalam koordinat $\mathrm{x}$ untuk nilai bending dan koordinat $\mathrm{z}$ untuk nilai buckling. $\mathrm{A} 0=\pi$.d.t dan D merupakann diameter rata-rata tube.

Dalam simulasi SWCNT Armchair dan zigzag ini, panjang awal telah ditentukan sebesar $1.7 \mathrm{~nm}$ untuk armchair dan 4.5 nm untuk zigzag. Dari hasil pembebanan bending dan buckling, Hasilnya menunjukkan countur warna yang menggambarkan tingkat kelenturan hasil dari displacement setiap titik atau dalam hal ini disebut atom carbon dalam SWCNT. Semakin mendekati titik constraint, maka tingkat kelenturan semakin rendah. Kelenturan maksimum berada ditengah. (Gambar 6)

\section{D.Pemodelan dengan Metode Elemen Hingga}

Penelitian ini menggunakan dimensi seperti pada tabel 1 untuk hasil simulasi dengan variasi diameter, sedangkan pada variasi ketebalan divariasikan menjadi 0.34, 0.6, 1.06, 1.4, $3.4 \mathrm{~nm}$. Geometri disimulasikan dengan pembebanan bending dan buckling dan diambil nilai displacement DOF sebagai nilai delta strain. Kemudian data diolah dengan menghitung Young's modulus menggunakan persamaan(10).

Pembebanan bending diameter antara 0.69-1.51 nm, didapatkan nilai Young's modulus sebesar 0.63-2.04 TPa untuk tipe armchair dan 0.24-1.58 Tpa untuk tipe zigzag. Sedangkan saat pembebanan buckling, didapatkan nilai Young's sebesar 0.09-0.19 Tpa untuk tipe armchair dan 0.040.09 Tpa untuk tipe zigzag.

Pembebanan bending ketebalan antara 0.34-3.4 nm, didapatkan nilai Young's modulus sebesar 0.91-0.09 TPa untuk tipe armchair dan 0.35-0.035 Tpa untuk tipe zigzag. Sedangkan saat pembebanan buckling, didapatkan nilai Young's modulus sebesar 9.5-0.9 Tpa untuk tipe armchair dan 0.46-0.046 Tpa untuk tipe zigzag.

Pembebanan bending dengan aspek rasio rentang 1.1262.464 didapatkan nilai Young's modulus sebesar 0.63-2.04 TPa untuk tipe armchair dan rentang 2.98-6.25 didapatkan nilai Young's sebesar 0.24-1.58 Tpa untuk tipe zigzag. Sedangkan saat pembebanan buckling, dengan aspek rasio rentang 1.126-2.464 didapatkan nilai Young's modulus sebesar 0.09-0.19 Tpa untuk tipe armchair. Rentang 2.98-6.25 didapatkan nilai Young's sebesar 0.04-0.09 Tpa untuk tipe zigzag.

Tabel 1

Informasi finite elemen yang digunakan dalam ansys

\begin{tabular}{cccccc}
\hline \hline $\begin{array}{c}\text { Chiral } \\
\text { Indeks }\end{array}$ & $\begin{array}{c}\mathbf{D} \\
(\mathbf{n m})\end{array}$ & $\begin{array}{c}\mathbf{t} \\
(\mathbf{n m})\end{array}$ & $\begin{array}{c}\mathbf{h} \\
(\mathbf{n m})\end{array}$ & $\begin{array}{c}\mathbf{F} \\
(\mathbf{N})\end{array}$ & $\begin{array}{c}\text { L/D } \\
(\mathbf{n m})\end{array}$ \\
\hline \multicolumn{7}{c}{ Armchair } \\
$(5,5)$ & 0.69 & 0.34 & $1.7 \mathrm{E}-08$ & $1.25 \mathrm{E}+11$ & 2.464 \\
$(6,6)$ & 0.83 & 0.34 & $1.7 \mathrm{E}-08$ & $1.25 \mathrm{E}+11$ & 2.048 \\
$(7,7)$ & 0.96 & 0.34 & $1.7 \mathrm{E}-08$ & $1.25 \mathrm{E}+11$ & 1.771 \\
$(10,10)$ & 1.38 & 0.34 & $1.7 \mathrm{E}-08$ & $1.25 \mathrm{E}+11$ & 1.232
\end{tabular}

1.126

\begin{tabular}{cccccc}
$(11,11)$ & 1.51 & 0.34 & $\begin{array}{r}1.7 \mathrm{E}-08 \\
\text { Zigzag }\end{array}$ & $1.25 \mathrm{E}+11$ & 1.126 \\
$(9,0)$ & 0.72 & 0.34 & 4.5 & $9.4 \mathrm{E}+10$ & 6.250 \\
$(10,0)$ & 0.79 & 0.34 & 4.5 & $9.4 \mathrm{E}+10$ & 5.696 \\
$(12,0)$ & 0.95 & 0.34 & 4.1 & $9.4 \mathrm{E}+10$ & 4.211 \\
$(18,0)$ & 1.35 & 0.34 & 4.0 & $9.4 \mathrm{E}+10$ & 3.037 \\
$(19,0)$ & 1.51 & 0.34 & 4.5 & $9.4 \mathrm{E}+10$ & 2.890 \\
\hline
\end{tabular}

Tipe Armchair mampu menahan beban bending dan buckling mencapai 125 Gpa, sedangkan tipe Zigzag mampu menahan beban maksimum $94 \mathrm{GPa}$. Dari keseluruhan simulasi pada tiga variabel berbeda menunjukkan bahwa tipe armchair memiliki nilai Young's modulus lebih besar dibandingkan tipe zigzag. Hal ini tentunya dipengaruhi oleh orientasi dari masing-masing tipe saat dikenai pembebanan. Seperti pada gambar 7. Hal ini seperti yang telah dijelaskan pada jurnal Prabhu, 2012 [5] dimana tipe zigzag gaya bereaksi hanya pada satu node hexagon saja, sedangkan tipe armchair terdapat dua gaya yang besarnya sama bereaksi pada dua node sebuah hexagon. (Gambar 8) Hal ini menunjukkan perbedaan pola struktur pembebanan meski gaya yang diberikan tetap. Sehingga besar Young's modulus dari kedua tipe CNT akan berbeda.

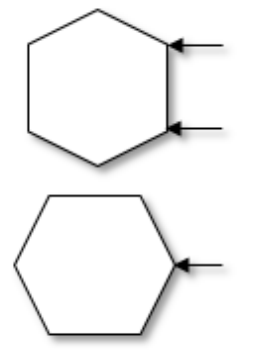

Armchair

Gambar 8. Orientasi pembebanan SWCNT

\section{E. Pengaruh Variasi Diameter}

Modulus elastisitas secara fungsi dan variabel convergen dengan Young's modulus pada lembar graphene pada diameter yang besar pada CNT. Alasan utamanya adalah karena murni dari kelengkungan tertinggi pada diameter yang kecil. Hal ini akan mengakibatkan distorsi atau perpindahan yang besar pada atom C-C pada diameter kecil CNT dibandingkan dengan diameter besar. Semakin besar diameter CNT, pengaruh kelengkungan akan semakin berkurang. [6] Hal ini juga ditunjukkan pada penelitian Giannopulous et al, [7] Meo dan Rossi, [8] serta Lu dan Hu. [9] yang menyatakan pengaruh diameter atau jari-jari pada hasil Young's modulus akibat kesensitivannya pada tingkat kelengkungan. Semakin besar diameter tube, maka shear modulus kecil karena menjadi kurang sensitive terhadap variasi jari-jari tabung namun meningkatkan nilai Young's modulusnya. Hal tersebut dapat ditunjukkan oleh hasil penelitian ini yang tergambar dalam grafik (gambar 9).

\section{F. Pengaruh Variasi Ketebalan}

Penelitian ini juga membahas mengenai efek ketebalan terhadap nilai Young's modulus. Penelitian ini mengambil variabel ketebalan berdasarkan perbedaan ketebalan pada mekanikal elemen yang digunakan, yaitu beaml88, yang 
terletak pada section. Hal ini dilakukan dengan dasar penelitian Tserpes dan Papanikos [10] yang menggunakan model finite elemen 3D untuk armchair, zigzag dan chiral pada SWCNT yang berdasarkan asumsi SWCNT berperilaku seperti struktur beam dibawah kondisi pembebanan. Mereka menyatakan nilai Youngs' modulus yang bervariasi antara 0.952 hinngga $1.066 \mathrm{TPa}$ dan modulus geser dari 0.242 hingga $0.504 \mathrm{TPa}$ dengan ketebalan yang digunakan adalah sebesar $0.34 \mathrm{~nm}$. Kemudian penelitian Pantato et al yang memodelkan tube individu menggunakan elemen shell dengan ketebalan spesifik $0.075 \mathrm{~nm}$ dan menghasilkan nilai Young's Modulus sebes ar $4.84 \mathrm{TPa}$.

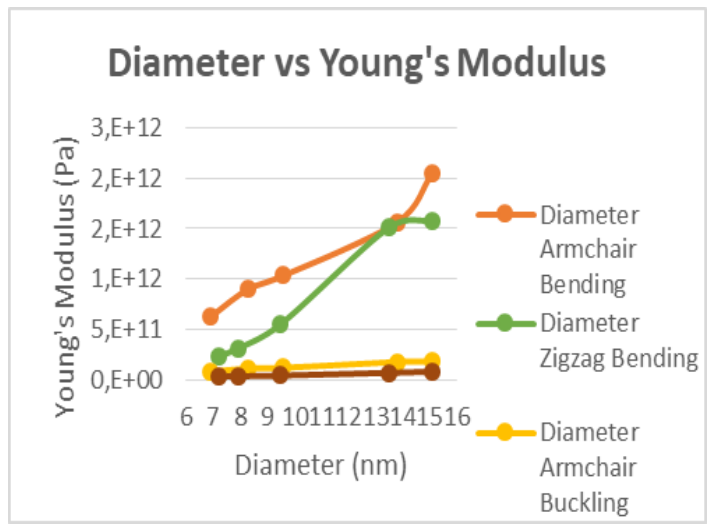

Gambar 9. Grafik perbandingan pengaruh diameter terhadap Young's modulus

Kemudian dijelaskan pula oleh penelitian Vodenitcharova and Zhang [10] yang mengenalkan konsep efektifitas ketebalan dinding dalam lingkup mekanika kontinum. Berdasarkan pertimbangannya akan gaya ekuilibrium, mereka mengusulkan mengenai kondisi yang diperlukan bahwa efektifitas ketebalan dinding SWCNT harus lebih kecil dari teori diameter atom karbon, yaitu sekitar $0.142 \mathrm{~nm}$. Argumennya mengenai cross-section nanotube berisi hanya jumlah atom dan gaya pada tube ditransmisikan melalui atomatom tersebut. Namun model mekanika kontinum, gaya yang sama ditransmisikan melalui luas area dinding. Oleh karenanya, efektivitas ketebalan dinding harus lebih kecil dari diameter atom karbon secara teoritis. Dengan kata lain, tube ekuilibrium tidak dapat dirubah. Berdasarkan kondisi tersebut, model continuum menggunakan ketebalan dinding lebih dari atau sama dengan diameter karbon adalah suatu hal yang tidak beralasan. Namun tentunya masih diperlukan validasi kembali mengenai hal tersebut.

Dari penelitian-penelitian tersebut dapat diketahui bahwa validitas dari ketebalan SWCNT sendiri masih dalam tahap penelitian, namun yang pasti ukurannya sendiri akan lebih kecil dari ukuran diameter atom karbon sebesar $3.4 \mathrm{~nm}$ dan merupakan hasil perubahan dari ikatan antar dua karbon yang diberikan gaya. Hal ini mendasari peneliti untuk menvariasikan ketebalan antara 0.34 hingga $3.4 \mathrm{~nm}$. Variasi tersebut diambil dari 10, 20, 30, 40 dan 100 persen dari besar atom karbon.

Gambar 10 menggambarkan grafik hasil pembebanan bending dan buckling pada tipe armchair $(6,6)$ dan tipe zigzag $(9,0)$ yang masing-masing divariasikan dengan ketebalan 0.34, 0.6, 1.06, 1.4, dan $3.4 \mathrm{~nm}$. Simulasi tersebut menunjukkan nilai Young's modulus yang terus menurun ketika ketebalan CNT meningkat. Di perjelas lagi dengan tipe CNT yang berpengaruh yaitu ketebalan armchair pada saat bending lebih rendah tingkat kekakuannya dibanding saat diberikan pembebanan buckling. Berbeda dengan tipe zigzag yang lebih rendah kekakuannya saat diberikan pembebanan buckling disbanding pembebanan bending. Hal ini tentunya menggambarkan bahwa ketebalan berpengaruh pada tingkat kekakuan CNT yang akan berpengaruh pula pada nilai Young's modulusnya.

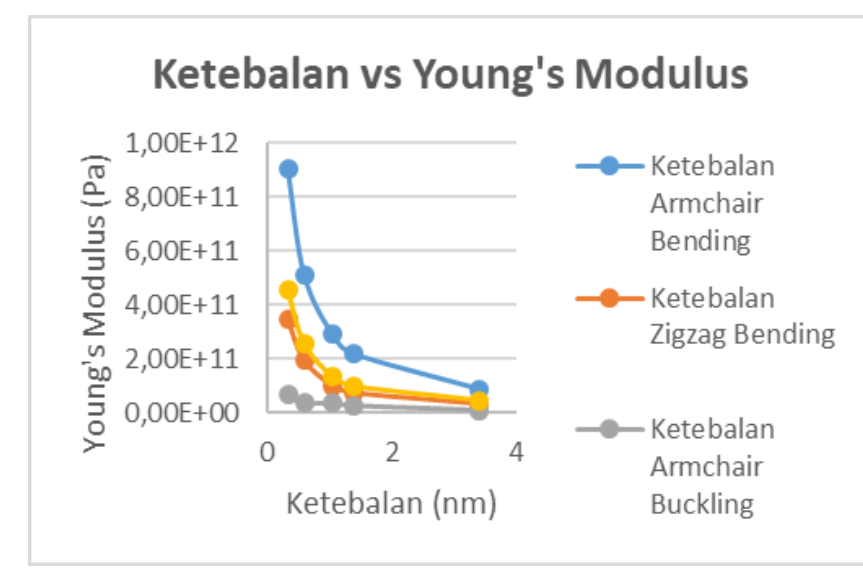

Gambar 10. Grafik perbandingan pengaruh ketebalan terhadap Young’s

Hal ini diperkuat oleh penelitian Gao et al [11] dan Odegard et al. [12] yang melakukan penelitian dengan finite model deformasi continuum menyatakan nilai Young's modulus inverse atau berkebalikan dengan luas permukaan A0 dan ketebalan t.

\section{KESIMPULAN/RINGKASAN}

Penelitian ini telah memformulasikan komputasi 3D finite element untuk respon mekanik elastisitas dari SWCNT tipe armchair dan zigzag dalam variasi diameter dan ketebalan. Dalam memodelkan material nano, digunakan tipe linear elastis elemen beamyang disimulasikan secara efektif force field dan interaksi interatomic antar atom karbon. Pembebanan bending dan buckling digunakan untuk menghitung besar nilai Young's modulus. Tipe armchair mampu memberikan nilai Young's modulus lebih besar dibandingkan dengan tipe zigzag. Hasilnya cenderung konvergen untuk diameter yang lebih besar dengan ketebalan $0.34 \mathrm{~nm}$. Hasilnya pun dapat dikatakan sesuai dengan literature. Sangat diharapkan adanya penelitian lebih lanjut untuk aplikasi dari masing-masing tipe struktur single walled carbon nanotube berdasarkan nilai Young's Modulus dari penelitian-penelitian yang sudah ada.

\section{DAFTAR PUSTAKA}

[1] P. J. F. Harris, Carbon Nanotube Composites. 2004.

[2] S. . Lee, J.-H, Rhee, K.Y., \&Park, "Silane modification of carbon nanotubes and its effects on the material properties of carbon/CNT/epoxy three-phase composites," Compos. Part A Appl. Sci. Manuf., vol. 42, no. 5, pp. 478-483, 2011.

[3] I. T. Iijima S, "Single-shell carbon nanotubes of $1-\mathrm{nm}$ diameter," 1993.

[4] O'Connel, Carbon Nanotubes Properties and Application. California: Senior Research cientist, Theranos, Inc, 2006.

[5] and V. Prabhu, S. Shubrajit, "Finite Element Modeling and 
Ansys of Zigzag and Armchair Type Single Wall Carbon Nanotube," vol. 4, no. 8, pp. 260-266, 2012.

[6] R. . Prabhu, "Finite Element Modelling of Multiwalled Carbon Nanotube," National Institute of Technology Rourkela, 2010.

[7] Giannopoulos, "Evaluation of the effective mechanical properties of single walled carbon nanotubes using a spring based finite element approach," Comput. Mater. Sci., pp. 561-569, 2008.

[8] R. M. Meo M, "Prediction of Young's modulus of single wall carbon nanotubes by molecular-mechanics based finite element modeling," Compos Sci Technol, pp. 1597-605, 2006.
[9] L. dan Hu, "Mechanical property evaluation of single-walled carbon nanotubes by finite element modeling," pp. 19021913, 2012.

[10] Z. and Wang, "Effective Wall Thickness of Single-Walled Carbon Nanotube for Multi-Scale Analysis: The Problem and a Possible Solution," in IUTAM symphosium, 2009, pp. 5361.

[11] B. Gao, Chem. Phys. Lett. 2000.

[12] N. L. M. and W. K. E. Odegard G M, Gates T S, "Equivalentcontinuum modelling of nanostructured materials," Compos. Sci. Technol, pp. 1869-80, 2002. 